\title{
Preparation and Tunable Luminescence of Eu Doped KNN Ceramics
}

\author{
WANG Meng-Hui ${ }^{1}$, SHEN Hui ${ }^{1,2}$, TIAN Tian ${ }^{1}$, XIAN Qin ${ }^{1}$, XU Jia-Yue ${ }^{1}$, JIN Min $^{3}$, JIA Run-Ping ${ }^{1}$ \\ (1. School of Materials Science and Engineering, Shanghai Institute of Technology, Shanghai 201418, China; 2. State Key \\ Laboratory of Crystal Materials, Shandong University, Jinan 250100, China; 3. School of Materials Science and Engineering, \\ Shanghai Dianji University, Shanghai 201306, China)
}

\begin{abstract}
Rare-earth doped inorganic ferroelectrics are considered as novel photochromic materials, with potential applications for optical switch and information storage $\left(\mathrm{K}_{0.5} \mathrm{Na}_{0.5}\right)_{1-x} \mathrm{Eu}_{x} \mathrm{NbO}_{3}(\mathrm{KNN}: x \mathrm{Eu})$ ceramics were prepared by high temperature calcination, with precursor powder obtained by hydrothermal method. Strong red emission at $615 \mathrm{~nm}$ was observed which corresponds to the ${ }^{5} \mathrm{D}_{0} \rightarrow{ }^{7} \mathrm{~F}_{2}$ transition of $\mathrm{Eu}^{3+}$ under excitation of $465 \mathrm{~nm}$. Under UV light irradiation for $3 \mathrm{~min}$, the color of the ceramics turned from milky white to dark gray. The colored samples returned to the original color when heated at $200{ }^{\circ} \mathrm{C}$ for $10 \mathrm{~min}$, showing strong photochromic behavior. Meanwhile, the luminescence intensity of $\mathrm{Eu}^{3+}$ can be tuned without obvious degradation by alternating UV light and heat stimulus. Upon UV light irradiation, large luminescence modulation ratio $\left(\Delta R_{\mathrm{t}}\right)$ up to $83.9 \%$ was achieved for $\mathrm{KNN}: 0.06 \mathrm{Eu}$, indicating good luminescence switching behavior. A possible mechanism for non-radiative energy transfer from the luminescent center to the color center was proposed according to their luminescent behavior.
\end{abstract}

Key words: $\mathrm{K}_{0.5} \mathrm{Na}_{0.5} \mathrm{NbO}_{3}(\mathrm{KNN})$; luminescence; photochromism

Photochromic (PC) materials, changing color between the coloring state and bleaching state upon light irradiation, have aroused increasing attention with great potential applications in photo-switching and related optoelectronic devices $^{[1-4]}$. Compared with traditional organic PC system, inorganic materials exhibit better thermal stability, higher chemical and fatigue resistance ${ }^{[5-7]}$. Some inorganic materials have been reported for their PC behaviors, such as $\mathrm{WO}_{3}, \mathrm{TiO}_{2}$, and $\mathrm{V}_{2} \mathrm{O}_{5}{ }^{[7-9]}$. However, the luminescence modulations of these materials are extremely poor, which limit their potential application for optical data storage. Recently, rare-earth element doped ferroelectric ceramics, including $\mathrm{K}_{0.5} \mathrm{Na}_{0.5} \mathrm{NbO}_{3}$ (KNN), $\mathrm{Na}_{0.5} \mathrm{Bi}_{2.5} \mathrm{Nb}_{2} \mathrm{O}_{9}(\mathrm{NBN})$ and $\mathrm{Na}_{0.5} \mathrm{Bi}_{4.5} \mathrm{Ti}_{4} \mathrm{O}_{15}$ (NBT), have been reported to show good luminescence switching behaviors ${ }^{[10-11]}$. Rare earth doped ferroelectrics are capable of combining ferroelectric energy storage and optical memories, which make them fascinating candidates as high density information storage media ${ }^{[12]}$.

$\mathrm{K}_{0.5} \mathrm{Na}_{0.5} \mathrm{NbO}_{3}(\mathrm{KNN})$ lead-free piezoelectric ceramics have been considered as the substitute for lead zirconate titanate (PZT) due to the large piezoelectric coeffiecient $\left(d_{33}\right)$ and high Curie temperature $\left(T_{\mathrm{C}}\right)^{[13-14]}$. Now, $\mathrm{KNN}: \mathrm{Er}^{3+}$ and $\mathrm{KNN}: \mathrm{Er}^{3+} / \mathrm{Yb}^{3+}$ display the upconversion luminescence modulation performance ${ }^{[15-17]}$. With visible light irradiation, the luminescent switching contrast $\left(\Delta R_{\mathrm{t}}\right)$ up to about $60 \%$ is observed in $\mathrm{KNN}: \mathrm{Sm}^{3+}$ ceramics ${ }^{[18]}$. $\mathrm{Eu}^{3+}$ doped inorganic materials have also been proved to possess excellent photochromic behavior under UV irradiation, like $\mathrm{Sr}_{2} \mathrm{SnO}_{4}: \mathrm{Eu}^{3+}, \mathrm{BaMgSiO}_{4}: \mathrm{Eu}^{3+}, \mathrm{Sr}_{3} \mathrm{SnMO}_{7}$ : $\mathrm{Eu}^{3+[19-21]}$. The underlying mechanism may be various from the valence state transition of $\mathrm{Eu}^{3+}$ to volatilizationinduced photochromism ${ }^{[19]}$. Upon to now, photoluminescence and ferroelectric property of $\mathrm{KNN}: \mathrm{Eu}^{3+}$ have been studied, while its luminescence based on PC reactions has not been reported ${ }^{[22-23]}$.

In this study, $\mathrm{Eu}^{3+}$ doped $\mathrm{K}_{0.5} \mathrm{Na}_{0.5} \mathrm{NbO}_{3}(\mathrm{KNN}: x \mathrm{Eu})$ powder with uniform morphology was fabricated by the hydrothermal method. KNN: $x$ Eu ceramics were obtained by calcining the precursor powder at high temperature. Hydrothermal method displays many merits in regulating the grains size, distribution and lower preparation temperature. Upon UV light irradiation and thermal stimulus, $\mathrm{KNN}: x \mathrm{Eu}$ ceramics display both photochromic reaction and tunable luminescence behavior with excellent reversibility. High value of $\Delta R_{\mathrm{t}}$ (up to $83.9 \%$ ) is achieved for $\mathrm{KNN}: 0.06 \mathrm{Eu}$. Possible luminescence switching mechanism was also proposed, regarding the energy

Received date: 2019-03-12; Revised date: 2019-04-29

Foundation item: National Natural Science Foundation of China (61605116, 51972213); Science and Technology Commission of Shanghai Municipality (15ZR1440600, 15520503400)

Biography: WANG Meng-Hui (1993-), Master candidate. E-mail: WMH_FZS@163.com 王梦慧, (1993-), 硕士研究生. E-mail: WMH_FZS@163.com

Corresponding author: SHEN Hui, associate professor. E-mail: hshen@sit.edu.cn; XU Jia-Yue, professor. E-mail: xujiayue@sit.edu.cn 申 慧, 副教授. E-mail: hshen@sit.edu.cn; 徐家跃, 教授.E-mail: xujiayue@sit.edu.cn 
transfer between luminescence center and color center.

\section{Experimental}

The $\mathrm{Eu}^{3+}$ doped $\mathrm{K}_{0.5} \mathrm{Na}_{0.5} \mathrm{NbO}_{3}(\mathrm{KNN}: x \mathrm{Eu})(x=0,0.02$, $0.04,0.06,0.08,0.10)$ precursor powder was prepared by the hydrothermal method. Sodium hydroxide $(\mathrm{NaOH})$, potassium hydroxide $(\mathrm{KOH})$, niobium pentoxide $\left(\mathrm{Nb}_{2} \mathrm{O}_{5}\right)$ and europia (III) oxide $\left(\mathrm{Eu}_{2} \mathrm{O}_{3}\right)$ served as raw materials. First, $\mathrm{KOH}$ and $\mathrm{NaOH}$ were weighed according to $\mathrm{K}^{+} / \mathrm{Na}^{+}$ratio of $3: 1$. They dissolved in distilled water to form a solution in which the concentration of $\mathrm{OH}^{-}$ changed from $10 \mathrm{~mol} / \mathrm{L}$ to $12 \mathrm{~mol} / \mathrm{L}$. Thereafter, $\mathrm{Nb}_{2} \mathrm{O}_{5}$ was added to the above solution and stirred for $30 \mathrm{~min}$. The obtained suspension was placed in a $100-\mathrm{mL}$ reaction kettle up to $70 \%$ of the total volume. Then the reaction kettle was sealed in a stainless-steel tank and heated at $200{ }^{\circ} \mathrm{C}$ for $12 \mathrm{~h}$. The resulting products were obtained by centrifugation, washing and drying. The synthesized powders were granulated with $6 \mathrm{wt} \%$ polyvinyl alcohol (PVA) binder, and then pressed into $12 \mathrm{~mm}$ disk-shaped pellets. KNN: $x$ Eu ceramics were prepared by calcination at $1140{ }^{\circ} \mathrm{C}$ for $4 \mathrm{~h}$.

The crystal structure was characterized by powder X-ray diffraction (D/max-2400, Rigaku, Japan) using a $\mathrm{Cu} \mathrm{K} \alpha$ radiation. The microstructures of the ceramics were analyzed by scanning electron microscopy (S-4800, Hitachi, Japan). The UV-VIS-NIR spectrophotometer (Cary 5000, Agilent) were used to test the diffuse reflectance spectra. The coloration of the ceramics was carried out under the UV-light $(\lambda<400 \mathrm{~nm})$ output of a $300 \mathrm{~W}$ Xe lamp (PLS-SXE300, Beijing Zhongjiaojinyuan Technology Co. Ltd). The luminescence spectra and luminescence quenching behavior (at 300, 350, 390, 407 and $450 \mathrm{~nm}$ ) were characterized by a fluorescence spectrophotometer (F-7000, Hitachi, Japan).

\section{Results and discussion}

Fig. 1(a) shows the XRD patterns of the KNN precursor powder synthesized at $200{ }^{\circ} \mathrm{C}$ for $12 \mathrm{~h}\left(\mathrm{~K}^{+} / \mathrm{Na}^{+}=3: 1\right)$ with $\left[\mathrm{OH}^{-}\right]$concentration from $10 \mathrm{~mol} / \mathrm{L}$ to $12 \mathrm{~mol} / \mathrm{L}$. When $\left[\mathrm{OH}^{-}\right]$was $10 \mathrm{~mol} / \mathrm{L}$, small amount of $\mathrm{NaNbO}_{3}$ was observed in the sample, except for the main perovskite phase of KNN (PDF \#77-0038). With the increase of $\left[\mathrm{OH}^{-}\right]$from $11 \mathrm{~mol} / \mathrm{L}$ to $12 \mathrm{~mol} / \mathrm{L}$, the $\mathrm{NaNbO}_{3}$ phase gradually disappeared. This result indicates that slight increase of $\left[\mathrm{OH}^{-}\right]$concentration can speed up the reaction process and facilitate the formation of pure KNN phase. Fig. 1(b) shows XRD patterns of the $\mathrm{KNN}: x \mathrm{Eu}(x=0.02,0.04,0.06,0.08,0.10)$ powders obtained by the hydrothermal method. Pure KNN phase has
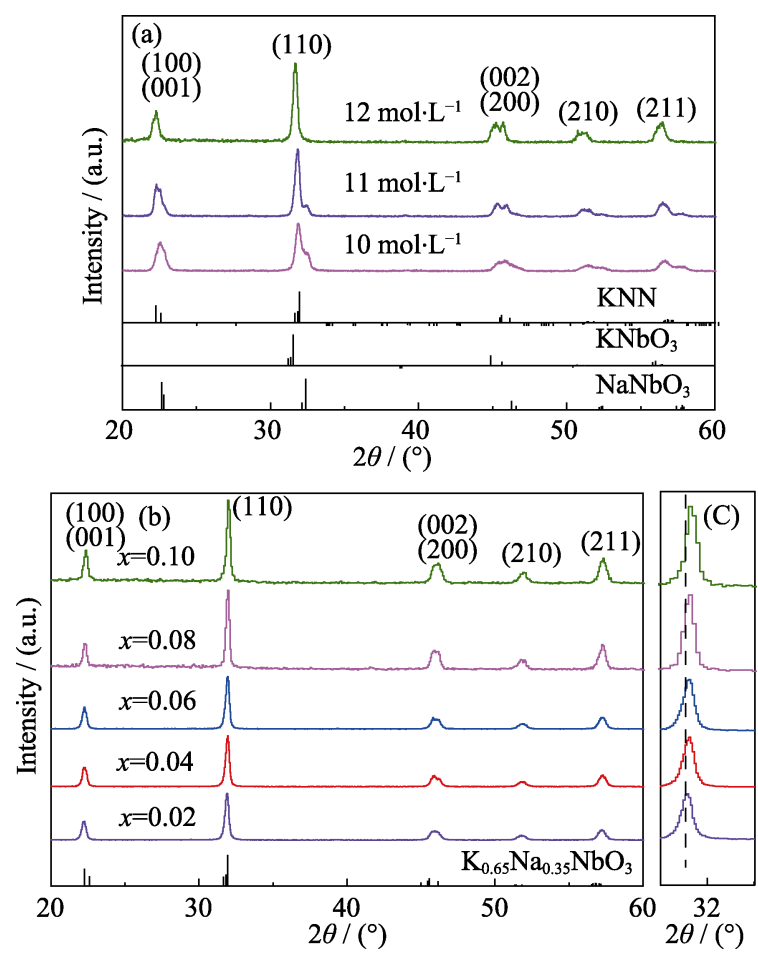

Fig. 1 XRD patterns of the precursor powders synthesized at $200{ }^{\circ} \mathrm{C}$ for $12 \mathrm{~h}\left(\mathrm{~K}^{+} / \mathrm{Na}^{+}=3: 1\right)$ with different $\left[\mathrm{OH}^{-}\right]$concentrations (a), XRD patterns of $\mathrm{KNN}: x \mathrm{Eu}(x=0.02,0.04,0.06,0.08$, $0.10)$ powders synthesized at $200{ }^{\circ} \mathrm{C}$ for $12 \mathrm{~h}\left(\mathrm{~K}^{+} / \mathrm{Na}^{+}=3: 1\right.$, $\left[\mathrm{OH}^{-}\right]=11 \mathrm{~mol} / \mathrm{L}$ ) (b) and zoomed XRD patterns from (b) within $30^{\circ}-33^{\circ}$ (c)

been obtained with $\left[\mathrm{OH}^{-}\right]$of $11 \mathrm{~mol} / \mathrm{L}$, indicating that $\mathrm{Eu}^{3+}$ is helpful for the formation of pure KNN phase. In Fig. 1(c), with increasing $\mathrm{Eu}^{3+}$ concentration, (110) diffraction peak moves slightly to a higher angle, suggesting that $\mathrm{Eu}^{3+}$ has partly replaced $\mathrm{K}^{+}$and $\mathrm{Na}^{+}$of the $\mathrm{KNN}$ matrix. The ion radius of $\mathrm{Eu}^{3+}(0.112 \mathrm{~nm})$ is smaller than those of $\mathrm{Na}^{+}(0.139 \mathrm{~nm})$ and $\mathrm{K}^{+}(0.164 \mathrm{~nm})$, resulting in the shrink of the crystal lattice ${ }^{[22]}$.

Fig. 2 displays the surface morphology of the KNN:0.06Eu ceramics calcined at $1140{ }^{\circ} \mathrm{C}$. Regular grains with cubic shape are well crystallized, with average size of about $0.3 \mu \mathrm{m}$. This grain size is very similar

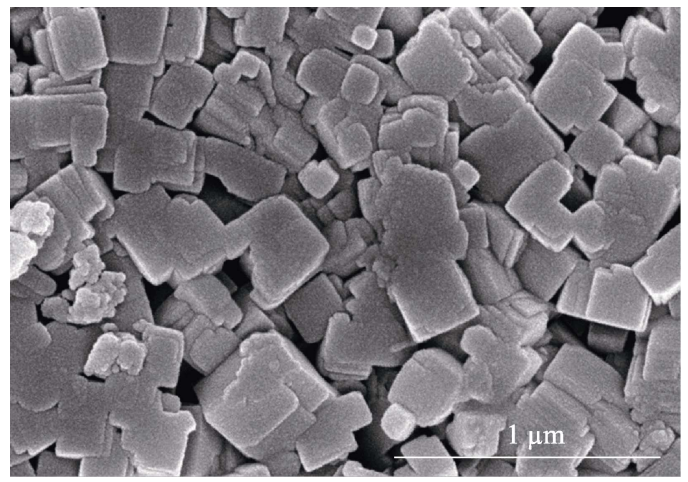

Fig. 2 SEM image of KNN:0.06Eu ceramics synthesized at $1140{ }^{\circ} \mathrm{C}$ for $4 \mathrm{~h}$ 
to those of hot-press sintered KNN ceramics and solidstate sintered KNN:Er ceramics ${ }^{[15,24]}$. Rare earth (like $\mathrm{Er}^{3+}$ and $\mathrm{Eu}^{3+}$ ) may inhibit the grain growth of KNN ceramics ${ }^{[15]}$. According to the EDS analysis, the molar ratio of $\mathrm{K}^{+}$and $\mathrm{Na}^{+}$of the ceramics is almost 0.78 , which is different from the initial composition. The radius of $\mathrm{K}^{+}$ $(0.164 \mathrm{~nm})$ is much bigger than that of $\mathrm{Na}^{+}(0.139 \mathrm{~nm})$, so it is much more difficult for $\mathrm{K}^{+}$to diffuse into the crystal lattice $^{[25]}$.

Fig. 3(a) shows the photoluminescence excitation (PLE) spectra of the KNN:0.06 ceramic and photoluminescence (PL) spectra of KNN: $x$ Eu ceramics. The PLE spectrum monitored at $618 \mathrm{~nm}$ reveals three characteristic absorption peaks, wherein the band at $395 \mathrm{~nm}$ corresponding to the ${ }^{7} \mathrm{~F}_{0} \rightarrow{ }^{5} \mathrm{~L}_{6}$ transition, the $465 \mathrm{~nm}$ band corresponding to the ${ }^{7} \mathrm{~F}_{0} \rightarrow{ }^{5} \mathrm{D}_{2}$ and the $526 \mathrm{~nm}$ band corresponding to the ${ }^{7} \mathrm{~F}_{0} \rightarrow{ }^{5} \mathrm{D}_{1}$. The emission spectra excited at $465 \mathrm{~nm}$ of KNN: $x$ Eu ceramics consists of a group of intense and sharp characteristic lines ranging within 570-750 nm, which mainly result from the characteristic f-f transition from the excited states ${ }^{5} \mathrm{D}_{0}$ to the ground state ${ }^{7} \mathrm{~F}_{\mathrm{J}}(\mathrm{J}=0-4)$ of $\mathrm{Eu}^{3+}$ ions ${ }^{[23]}$. The strongest red emission at $615 \mathrm{~nm}$ comes from the ${ }^{5} \mathrm{D}_{0} \rightarrow{ }^{7} \mathrm{~F}_{2}$ of $\mathrm{Eu}^{3+}$. The positions of emission peak and line shape of the emission spectra maintain the same, but the emission intensity of $\mathrm{Eu}^{3+}$ is a function of its doping concentration. With the increase of
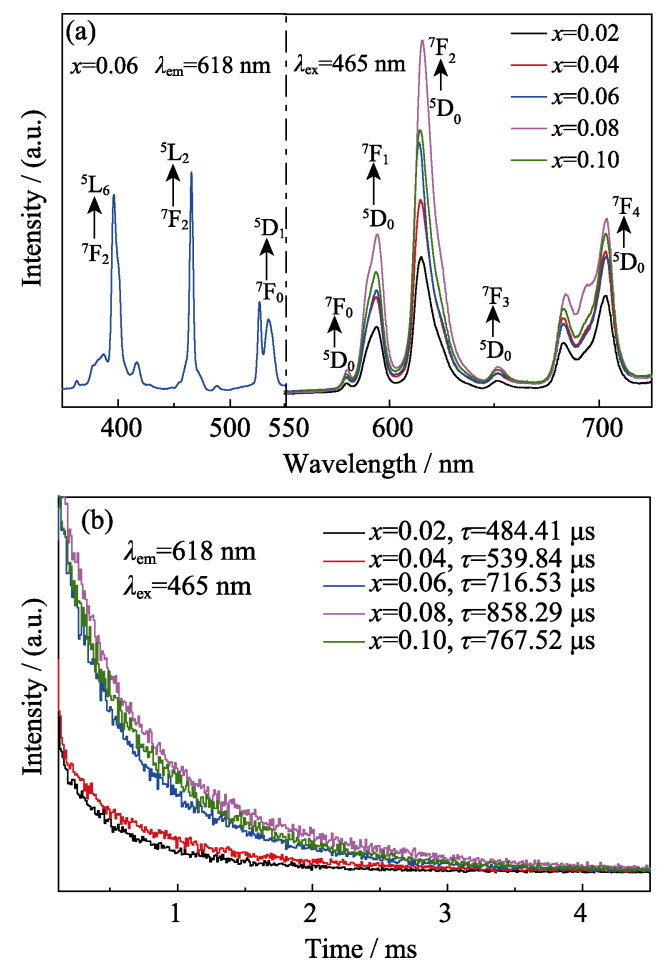

Fig. 3 Excitaion $\left(\lambda_{\mathrm{em}}=618 \mathrm{~nm}\right)$ spectra of the $\mathrm{KNN}: 0.06 \mathrm{Eu}$ ceramics and emission $\left(\lambda_{\mathrm{ex}}=465 \mathrm{~nm}\right)$ spectra of $\mathrm{KNN}: x \mathrm{Eu}$ ceramics at room temperature (a) and the dynamic decay curves on $\mathrm{Eu}^{3+}$ concentrations for $\mathrm{KNN}$ :Eu samples under 465 excitation (b)
$\mathrm{Eu}^{3+}$ concentration, the red emission intensity gradually increased and reached maximum when $x=0.08$. The intensity decreases gradually beyond this critical concentration.

The dynamic decay curves on $\mathrm{Eu}^{3+}$ concentrations for KNN:Eu ceramics under $465 \mathrm{~nm}$ excitation are shown in Fig. 3(b). The lifetimes are well fitted by using second-order exponential as follows:

$$
I(t)=I_{0}+\mathrm{A}_{1} \exp \left(-t / \tau_{1}\right)+A_{2} \exp \left(-t / \tau_{2}\right)
$$

Where $I_{0}$ is the emission intensity at $t_{0}, A_{1}$ and $A_{2}$ are constant, $\tau_{1}$ and $\tau_{2}$ are the lifetimes of the exponential component.

$$
\tau=\left(A_{1} \tau_{1}^{2}+A_{2} \tau_{2}^{2}\right) /\left(A_{1} \tau_{1}+A_{2} \tau_{2}\right)
$$

With $\mathrm{Eu}^{3+}$ concentration increasing, the average lifetime gradually increases and reaches maximum when $x=0.08$, which is mainly related to the radiative energy transfer between $\mathrm{Eu}^{3+}$ neighbor ions. With $\mathrm{Eu}^{3+}$ concentration further increasing, the ion distance between $\mathrm{Eu}^{3+}-\mathrm{Eu}^{3+}$ becomes shorter, possibly resulting in the decrease of average lifetime ${ }^{[26-27]}$.

Fig. 4 shows the reflectance spectra and photochromic reaction of KNN: $x$ Eu ceramics under UV irradiation and thermal stimulus. Fig. 4(a) gives the reflection spectra of KNN:0.06Eu ceramic irradiated under UV light for different time ( $0 \mathrm{~s}$ to $3 \mathrm{~min}$ ). The reflection intensity decreases significantly in the region $400-750 \mathrm{~nm}$ with increasing irradiation time, indicating that the irradiated sample absorbs part of the visible light. The absorption ratio can be evaluated by comparing the difference of the reflective intensity before $\left(\mathrm{RE}_{1}\right)$ and after $\left(\mathrm{RE}_{2}\right)$ irradiation using the formula: $\Delta a b s=R_{1}-R_{2}(\%)^{[28]}$. Fig. 4(b) shows that $\mathrm{KNN}: 0.06 \mathrm{Eu}$ has a broad absorption from $400 \mathrm{~nm}$ to $750 \mathrm{~nm}$, with the absorption maximum at about $566 \mathrm{~nm}$. In the inset of Fig. 4(b), upon UV light irradiation for $3 \mathrm{~min}$, the color of the sample turns from milky white to gray as a colored sample. The colored sample recovered its initial stage when heated at $200{ }^{\circ} \mathrm{C}$ for $10 \mathrm{~min}$ (marked as $\Delta$ ). In Fig. 4(c), KNN:0.06Eu ceramic shows the best photochromic behavior, which is indicated by the change of $\Delta$ abs (at $566 \mathrm{~nm}$ ) with $\mathrm{Eu}^{3+}$ concentration. KNN:0.06Eu ceramic is treated repeatedly with UV light irradiation (3 $\mathrm{min}$ ) and thermal stimulus $\left(200{ }^{\circ} \mathrm{C}\right.$ for $\left.10 \mathrm{~min}\right)$. As seen in Fig. 4(d), the reflectance intensity at $566 \mathrm{~nm}$ shows no obvious degradation for 10 cycles, showing good fatigue resistance of the color switching.

The photoluminescence spectra of KNN:0.06Eu ceramics before and after UV irradiation for $3 \mathrm{~min}$ are shown in Fig. 5(a). Upon UV light irradiation, the luminescence intensity decreases significantly, showing strong luminescence quenching effect. The quenching behavior may be explained by the parameter $\Delta R_{\mathrm{t}}$ (luminescence 

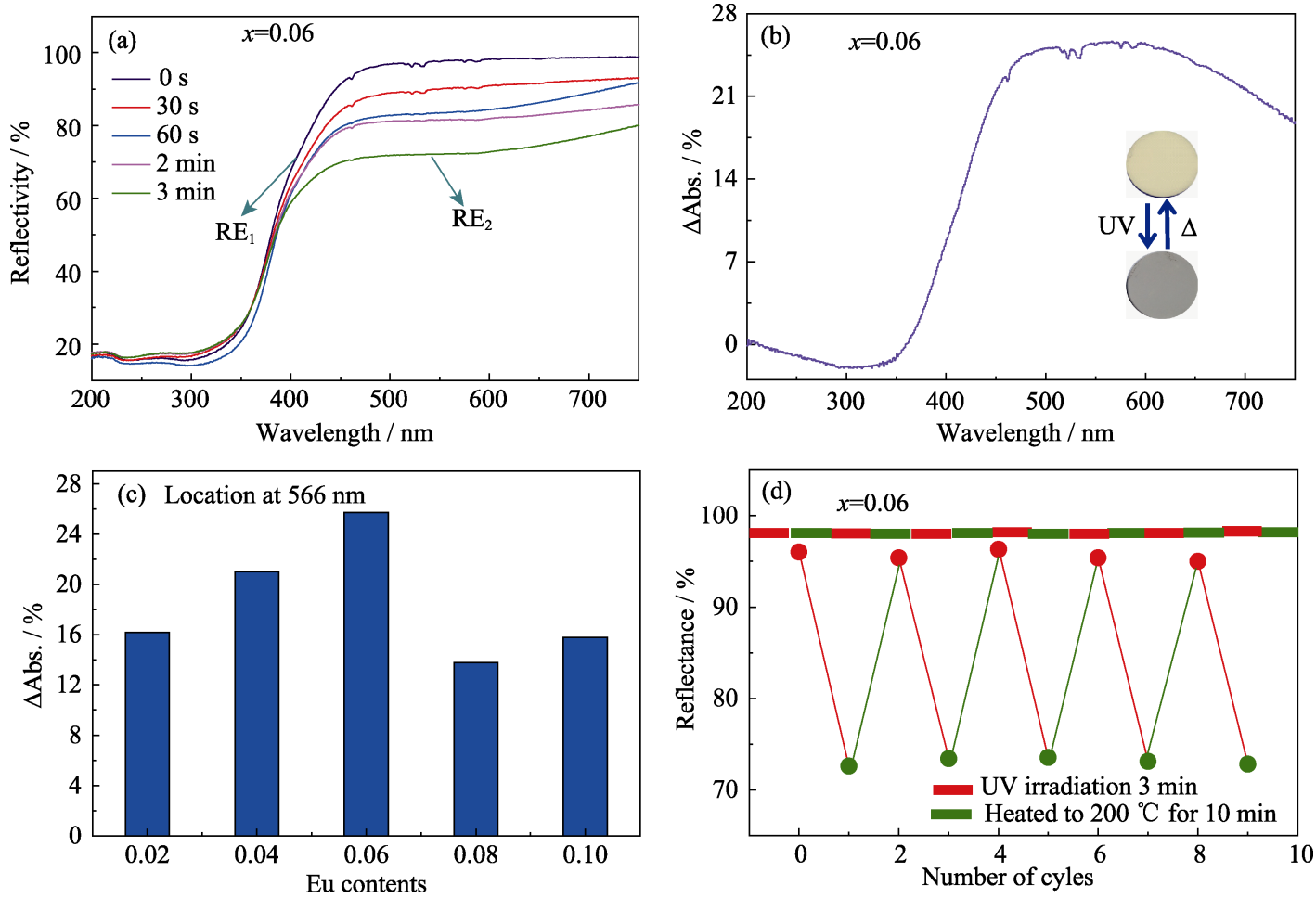

Fig. 4 Reflectance spectra for the KNN:0.06Eu by UV light irradiation ( $0 \mathrm{~s}, 30 \mathrm{~s}, 60 \mathrm{~s}, 2$ and 3 min) (a), difference absorption ( $\triangle \mathrm{abs}$ ) spectra for the KNN:0.06Eu by UV irradiation $3 \mathrm{~min}$ with inset showing photographs of color changes of ceramic before and after UV irradiation (b), the $\Delta$ abs $v s$ Eu concentration (c) and reflectance intensity changes (d) of KNN:0.06Eu by alternating UV irradiation and heat treatment

modulation ratio) using the equation: $\Delta R_{\mathrm{t}}=\left(R_{0}-R_{\mathrm{t}}\right) / R_{0}$ $\times 100(\%)$, where $R_{0}$ and $R_{\mathrm{t}}$ are the luminescence intensity before and after light irradiation, respectively ${ }^{[10,15]}$. Fig. 5(b) shows the change of $\Delta R_{\mathrm{t}}$ at $615 \mathrm{~nm}$ as a function of Eu concentration. Upon UV light irradiation for $3 \mathrm{~min}$, the emission intensities of all samples decreased significantly. The calculated $\Delta R_{\mathrm{t}}$ values of the KNN:xEu samples are $34.2 \%(x=0.02), 47.6 \% \quad(x=0.04), 83.9 \%$ $(x=0.06), 46.4 \%(x=0.08)$ and $48.3 \%(x=0.10)$, respectively. The maximum $\Delta R_{\mathrm{t}}$ value $(83.9 \%)$ is achieved for $\mathrm{KNN}: 0.06 \mathrm{Eu}^{3+}$, which is comparably high among rare earth doped KNN ferroelectrics.

Furthermore, KNN:0.06Eu ceramic was subjected to alternating UV light irradiation (3 min) and the thermal stimulus $\left(200{ }^{\circ} \mathrm{C}\right.$ for $10 \mathrm{~min}$ ) for 7 cycles. For each cycle, the PL spectra were recorded immediately after UV light irradiation and the thermal stimulus. Accordingly, $\Delta R_{\mathrm{t}}$ at $615 \mathrm{~nm}$ was calculated and the result was shown in Fig. 5(c). The decreased emission intensity after UV irradiation is able to almost recover its initial state upon heating treatment. $\Delta R_{\mathrm{t}}$ has no obvious degradation for at least 7 cycles, illustrating good reversibility of the luminescence switching.

In order to further investigate the effect of irradiation wavelength on the tunability of luminescence, the emission spectra of KNN:0.06Eu ceramic $\left(\lambda_{\mathrm{ex}}=465 \mathrm{~nm}\right)$ under
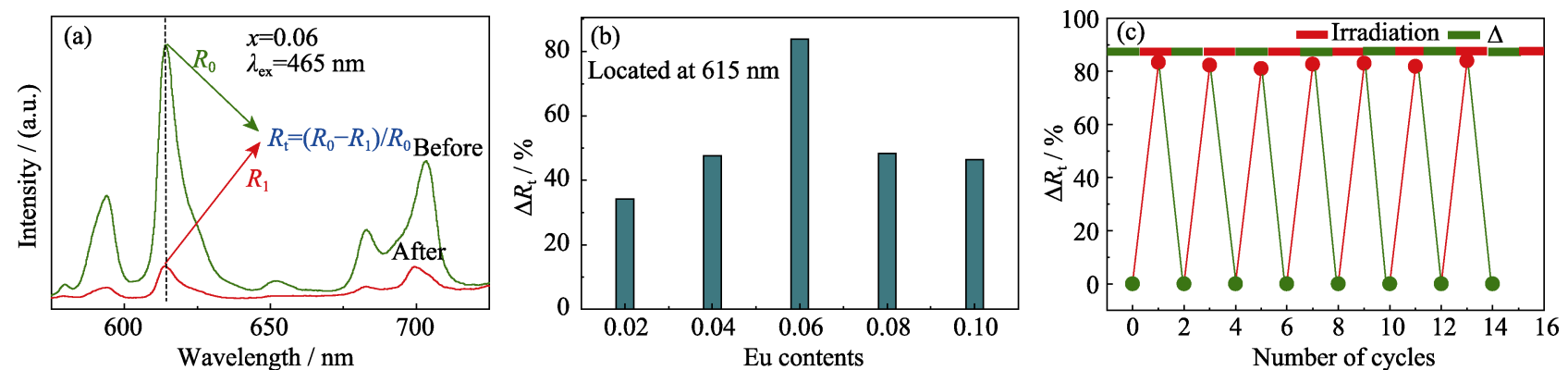

Fig. 5 Changes of emission spectra $\left(\lambda_{\mathrm{ex}}=465 \mathrm{~nm}\right.$ ) of KNN:0.06 Eu ceramics before and after UV irradiation for $3 \mathrm{~min}$ (a), luminescence switching ratio $\left(\Delta R_{\mathrm{t}}\right)$ at $615 \mathrm{~nm}$ as a function of Eu concentration (b) and $\Delta R_{\mathrm{t}}$ of $\mathrm{KNN}: 0.06 \mathrm{Eu}$ ceramics by alternating UV light irradiation and thermal stimulus for 7 cycles (c) 

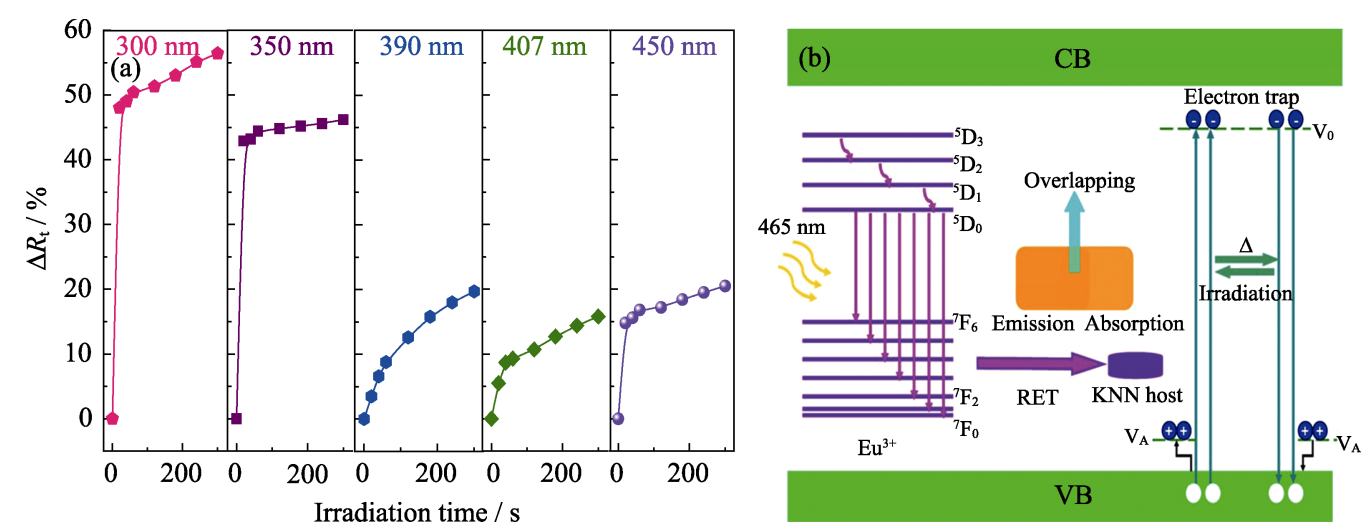

Fig. 6 Luminescence modulation ratio $\left(\Delta R_{\mathrm{t}}\right)$ as a function of irradiation time under different irradiation wavelengths (a) and schematic diagram of luminescence modulation upon photochromic reactions for KNN: $x$ Eu ceramics

( $\mathrm{V}_{\mathrm{O}}$ is oxygen vacancy, and $\mathrm{V}_{\mathrm{A}}$ is $\mathrm{K}$ and $\mathrm{Na}$ vacancy) (b)

different wavelength irradiation (300, 350, 390, 407 and $450 \mathrm{~nm}$ ) were measured, as shown in Fig. 6(a). For this experiment, a xenon lamp equipped with an F-7000 spectrometer acted as the irradiation light source. In Fig. 6(a), with irradiation time $(20 \mathrm{~s}, 40 \mathrm{~s}, 1 \mathrm{~min}, 2 \mathrm{~min}$, $3 \mathrm{~min}$ and $4 \mathrm{~min}$ ) increasing, $\Delta R_{\mathrm{t}}$ of the $\mathrm{KNN}: 0.06 \mathrm{Eu}$ gradually increases. $\Delta R_{\mathrm{t}}$ decreases dramatically with increasing irradiation wavelength, and the largest $\Delta R_{\mathrm{t}}$ is obtained with irradiation wavelength of $300 \mathrm{~nm}$. This result verifies that the luminescence of KNN:0.06Eu can be effectively tuned by UV light irradiation. There are some reports of $\mathrm{Eu}$ based photochromic materials which is also effectively excited by UV light, like $\mathrm{Sr}_{2} \mathrm{SnO}_{4}: \mathrm{Eu}^{3+}$, $\mathrm{BaMgSiO}_{4}: \mathrm{Eu}^{3+}, \mathrm{Sr}_{3} \mathrm{SnMO}_{7}: \mathrm{Eu}^{3+}$, although the origins of PC processes may be varied ${ }^{[19-21]}$.

Fig. 6(b) illustrates the possible mechanism of luminescence switching based on PC reactions. It may be explained by the free or trapped charge carrier and resonance energy transfer (RET) mechanism, which bases on the overlap of the emission band of $\mathrm{Eu}^{3+}$ ions and the absorption bands of photochromic KNN ceramics ${ }^{[29-30]}$. Due to many vacancy-related defects in KNN host, additional defect energy levels form within the forbidden gap of KNN. Upon UV light illumination, the electrons from the valence band (Ev) are excited to higher energy level (defect level), and are trapped by the oxygen vacancies $\left(\mathrm{V}_{\mathrm{o}}\right)^{[10,15]}$. The excited holes are also trapped by the $\mathrm{K}$ and $\mathrm{Na}$ vacancies $\left(\mathrm{V}_{\mathrm{A}}\right)$. Both of these defects are color centers which have a broad absorption band in the range from 400 to $700 \mathrm{~nm}$ (Fig. 4). The emission positions of $\mathrm{Eu}^{3+}$ overlaps with the absorption band range of these color centers (Fig. 3, 4 and 5). When $\mathrm{Eu}^{3+}$ is excited, the emission can be effectively absorbed by the color centers through the resonance energy transfer, resulting in the significant decrease of the $\mathrm{Eu}^{3+}$ luminescence intensity ${ }^{[19]}$. When the ceramic is heated to $200{ }^{\circ} \mathrm{C}$ for $10 \mathrm{~min}$, the colored sample fade back into their original color state. Meanwhile, electrons can be released from the traps and the color centers disappears. Correspondingly, the emission intensities of $\mathrm{Eu}^{3+}$ are also recovered.

The luminescence mechanism of $\mathrm{KNN}: x \mathrm{Eu}$ is similar with that of $\mathrm{Sr}_{3} \mathrm{SnMO}_{7}$ :Eu which is also irradiated by UV $(254 \mathrm{~nm})$ light $^{[19]}$. Other KNN based ceramics, like $\mathrm{KNN}: \mathrm{Er}, \mathrm{KNN}: \mathrm{Er} / \mathrm{Yb}, \mathrm{KNN}: \mathrm{Ho} / \mathrm{Yb}$ and $\mathrm{KNN}: \mathrm{Sm}$, have been reported to show photochromic and luminescence switching behavior by visible light $(407 \mathrm{~nm})$ illumination $^{[16-18]}$. Furthermore, the emission intensity reached maximum for $\mathrm{KNN}: 0.08 \mathrm{Eu}$, while the largest luminescence switching ratio is achieved for KNN:0.06Eu. The luminescence switching ratio mainly relates to the energy transfer between luminescence centers and color centers. And the color centers relates to the traps or defects within the host lattice. The unique feature of KNN: $x \mathrm{Eu}$ is possibly caused by the varied trap depths or distributions of defects within this system, which will be systematically studied in the future.

\section{Conclusions}

Eu doped $\mathrm{K}_{0.5} \mathrm{Na}_{0.5} \mathrm{NbO}_{3}$ (KNN: $x \mathrm{Eu}$ ) precursor powders were hydrothermally synthesized at $200{ }^{\circ} \mathrm{C}$ for $12 \mathrm{~h}\left(\mathrm{~K}^{+} / \mathrm{Na}^{+}=3: 1,\left[\mathrm{OH}^{-}\right]=11 \mathrm{~mol} / \mathrm{L}\right)$. The phase-pure perovskite $\mathrm{KNN}: x \mathrm{Eu}$ ceramics exhibit homogeneous morphology when calcined at $1140{ }^{\circ} \mathrm{C}$ for $4 \mathrm{~h}$. KNN:xEu ceramics show remarkable photochromic and luminescence switching behavior. Upon UV light irradiation, the sample colors change from the initial milky white to dark gray. By alternating UV irradiation and thermal stimulus, the luminescence modulation ratio $\left(\Delta R_{\mathrm{t}}\right)$ of $\mathrm{KNN}: 0.06 \mathrm{Eu}$ reach high values of $83.9 \%$. These results indicate that $\mathrm{KNN}: x \mathrm{Eu}$ system is a potential candidate for novel photo-electronic device. 


\section{References}

[1] WU N M, WONG H L, YAM V W. Photochromic benzo phosphole oxide with excellent thermal irreversibility and fatigue resistance in the thin film solid state via direct attachment of dithienyl units to the weakly aromatic heterocycle. Chemical Science, 2017, 8: 1309-1315.

[2] WANG R G, LU X L, HAO L F, et al. Enhanced and tunable photochromism of $\mathrm{MoO}_{3}$-butylamine organic-inorganic hybrid composites. Journal of Materials Chemistry C, 2017, 5: 427-433.

[3] HADJOUDIS E, MAVRIDIS I M. Photochromism and thermochromism of schiff bases in the solid state: structural aspects. Chemical Society Reviews, 2004, 33: 579-588.

[4] PANG S C, HYUN H, LEE S, et al. Photoswitchable fluorescent diarylethene in a turn-on mode for live cell imaging. Chemical Communications, 2012, 48: 3745-3747.

[5] ZHANG Y Y, LUO L H, LI K X, et al. Reversible up-conversion luminescence modulation based on UV-Vis light-controlled photochromism in $\mathrm{Er}^{3+}$ doped $\mathrm{Sr}_{2} \mathrm{SnO}_{4}$. Journal of Materials Chemistry C, 2018, 6: 13148-13156.

[6] RUSSO M, RIGBY S E J, CASERI W, et al. Pronounced photochromism of titanium oxide hydrates (hydrous $\mathrm{TiO}_{2}$ ). Journal of Materials Chemistry, 2010, 20: 1348-1356.

[7] NISHIO S, KAKIHANA M. Evidence for visible light photochromism of $\mathrm{V}_{2} \mathrm{O}_{5}$. Chemistry Materials, 2002, 14: 3730-3733.

[8] BLACKMAN C S, PARKINARKIN I P. Atmospheric pressure chemical vapor deposition of crystalline monoclinic $\mathrm{WO}_{3}$ and $\mathrm{WO}_{3-x}$ thin films from reaction of $\mathrm{WC}_{16}$ with O-containing solvents and their photochromic and electrochromic properties. Chemistry Materials, 2005, 17: 1583-1590.

[9] HOSONO E, FUJIHARA S, KAKIUCH K, et al. Growth of submicrometer-scale rectangular parallelepiped rutile $\mathrm{TiO}_{2}$ films in aqueous $\mathrm{TiCl}_{3}$ solutions under hydrothermal conditions. Journal of the American Chemical Society, 2004, 126: 7790-7791.

[10] ZHANG Q W, YUE S S, SUN H Q, et al. Nondestructive up-conversionreadout in $\mathrm{Er} / \mathrm{Yb}$ co-doped $\mathrm{Na}_{0.5} \mathrm{Bi}_{2.5} \mathrm{Nb}_{2} \mathrm{O}_{9}$-based optical storage materials for optical data storage device applications. Journal of Materials Chemistry C, 2017, 5: 3838-3847.

[11] ZHANG Q W, ZHANG Y Y, SUN H Q, et al. Tunable luminescence contrast of $\mathrm{Na}_{0.5} \mathrm{Bi}_{4.5} \mathrm{Ti}_{4} \mathrm{O}_{15}: \mathrm{Re}$ ( $\mathrm{Re}=\mathrm{Sm}, \mathrm{Pr}, \mathrm{Er}$ ) photochromics by controlling the excitation energy of luminescent centers. ACS Applied Matericals \& Interfaces, 2016, 8: 34581-34589.

[12] LI K X, LUO L H, ZHANG Y Y, et al. Tunable luminescence contrast in photochromic ceramics $(1-x) \mathrm{Na}_{0.5} \mathrm{Bi}_{0.5} \mathrm{TiO}_{3}-x \mathrm{Na}_{0.5} \mathrm{~K}_{0.5} \mathrm{NbO}_{3}$ : 0.002 Er by an electric field poling. ACS Applied Matericals \& Interfaces, 2018, 48: 41525-41534.

[13] ZHEN Y, LI J F. Normal sintering of (K, $\mathrm{Na}) \mathrm{NbO}_{3}$-based ceramics: influence of sintering temperature on densification, microstructure, and electrical properties. Journal of the American Chemical Society, 2006, 89: 3669-3675.

[14] SU L K, ZHU K J, BAI L, QIU J H, et al. Effects of Sb-doping on the formation of $(\mathrm{K}, \mathrm{Na})(\mathrm{Nb}, \mathrm{Sb}) \mathrm{O}_{3}$ solid solution under hydrothermal conditions. Journal of Alloys and Compounds, 2010, 493: 186-191.

[15] ZHANG Y Y, LUO L H, LI K X, et al. Up-conversion lumines- cence switching of $\left(\mathrm{K}_{0.5} \mathrm{Na}_{0.5}\right)_{0.995} \mathrm{Er}_{0.005} \mathrm{NbO}_{3}$ ferroelectric ceramic based on photochromic reaction. Ceramics International, 2018, 44: 1086-1090.

[16] LIU J, ZHANG Y, SUN H Q, et al. Reversible up-conversion emission and photo-switching properties in $\mathrm{Er}$ doped $(\mathrm{K}, \mathrm{Na}) \mathrm{NbO}_{3}$ ferroelectrics. Journal of Luminescence, 2019, 207: 85-92.

[17] ZHANG Y Y, LUO L H, LI K X, et al. Large and reversible in-situ up-conversion photoluminescence modulation based on photochromism via electric-field and thermal stimulus in ferroelectrics. Journal of European Ceramic Society, 2018, 38: 3154-3161.

[18] SUN H Q, LIU J, WANG X H, et al. (K, $\mathrm{Na}) \mathrm{NbO}_{3}$ ferroelectrics: a new class of solid-state photochromic materials with reversible luminescence switching behavior. Journal of Materials Chemistry C, 2017, 5: 9080-9087.

[19] WANG C L, JIN Y H, LV Y, et al. Reversible luminescence switching and non-destructive optical readout behaviors of $\mathrm{Sr}_{3} \mathrm{SnMO}_{7}: \mathrm{Eu}^{3+}(\mathrm{M}=\mathrm{Sn}, \mathrm{Si}, \mathrm{Ge}, \mathrm{Ti}, \mathrm{Zr}$, and $\mathrm{Hf})$ driven by photochromism and tuned by partial cation substitution. Sensors and Actuators B: Chemical, 2018, 262: 289-297.

[20] KAMIMURA S, YAMADA H, XU C N. Purple photochromism in $\mathrm{Sr}_{2} \mathrm{SnO}_{4}: \mathrm{Eu}^{3+}$ with layered perovskite-related structure. Applied Physics Letters, 2013, 102: 031110.

[21] AKIYAMA M. Blue-green light photochromism in europium doped $\mathrm{BaMgSiO}_{4}$. Applied Physics Letters, 2010, 97: 181905.

[22] WANG J, LUO L H. Probing the diffusion behavior of polymorphic phase transition in $\mathrm{K}_{0.5} \mathrm{Na}_{0.5} \mathrm{NbO}_{3}$ ferroelectric ceramics by $\mathrm{Eu}^{3+}$ photoluminescence. Journal of Applied Physics, 2018, 123: 144102.

[23] SUN H Q, ZHANG Q W, WANG X S, et al. New red-emitting material $\mathrm{K}_{0.5} \mathrm{Na}_{0.5} \mathrm{NbO}_{3}$ : Eu ${ }^{3+}$ for white LEDs. Materials Research Bulletin, 2015, 64: 134-138.

[24] GENG Z M, LI K, LI X, et al. Fabrication and photoluminescence of Eu-doped KNN based transparent ceramics. Journal of Materials Science, 2017, 52: 2285-2295.

[25] ZHOU Y, GUO M, ZHANG C, et al. Hydrothermal synthesis and piezoelectric property of Ta-doping $\mathrm{K}_{0.5} \mathrm{Na}_{0.5} \mathrm{NbO}_{3}$ lead-free piezoelectric ceramic. Ceramics International, 2009, 35: 3253-3258.

[26] ZHANG Y, XU J Y, YANG B B, et al. Luminescence properties and energy migration mechanism of $\mathrm{Eu}^{3+}$ activated $\mathrm{Bi}_{4} \mathrm{Si}_{3} \mathrm{O}_{12}$ as a potential phosphor for white LEDs. Materials Research Express, 2018, 5: 026202.

[27] WU X, CHUNG T H, KWOK K W. Enhanced visible and mid-IR emissions in $\mathrm{Er} / \mathrm{Yb}$-cooped $\mathrm{K}_{0.5} \mathrm{Na}_{0.5} \mathrm{NbO}_{3}$ ferroelectric ceramics. Ceramics International, 2015, 41: 14041-14048.

[28] SUN H Q, ZHANG Y, LIU JIAN, et al. Reversible upconversion switching for $\mathrm{Ho} / \mathrm{Yb}$ codoped $(\mathrm{K}, \mathrm{Na}) \mathrm{NbO}_{3}$ ceramics with excellent luminescence readout capability. Journal of the American Chemical Society, 2018, 101: 5659-5674.

[29] NIKL M. Wide band gap scintillation materials: progress in the technology and material understanding. Physica Status Solidi, 2000, 178: $595-620$.

[30] ZHANG Q W, ZHANG Y, SUN H Q, et al. Photoluminescence, photochromism, and reversible luminescence modulation behavior of Sm-doped $\mathrm{Na}_{0.5} \mathrm{Bi}_{2.5} \mathrm{Nb}_{2} \mathrm{O}_{9}$ ferroelectrics. Journal of European Ceramic Society, 2017, 37: 955-966. 


\section{Eu 掺杂 KNN 陶瓷的制备及可调性发光研究}

王梦慧 ${ }^{1}$, 申 慧 ${ }^{1,2}$, 田 甜 ${ }^{1}$, 鲜 琴 $^{1}$, 徐家跃 ${ }^{1}$ ，金 敏 $^{3}$, 贾润萍 ${ }^{1}$

(1. 上海应用技术大学 材料科学与工程学院, 上海 201418; 2. 山东大学 晶体材料国家重点实验室, 济南 $250100 ; 3$. 上海电机学院 材料科学与工程学院, 上海 201306)

摘 要: 稀土离子掺杂铁电陶瓷是一类新型光致变色材料, 在光开关、光信息存储等领域具有潜在应用价值。本研 究采用水热法制备了 $\left(\mathrm{K}_{0.5} \mathrm{Na}_{0.5}\right)_{1-x} \mathrm{Eu}_{x} \mathrm{NbO}_{3}(\mathrm{KNN}: x \mathrm{Eu})$ 前驱体粉体, 随后利用高温烧结得到对应陶瓷样品。在 $465 \mathrm{~nm}$ 激发下, 观察到 $615 \mathrm{~nm}$ 处有强的红色发光, 对应于 $\mathrm{Eu}^{3+}$ 的 ${ }^{5} \mathrm{D}_{0} \rightarrow^{7} \mathrm{~F}_{2}$ 跃迁。通过紫外光照射, $\mathrm{KNN}: \mathrm{Eu}$ 陶瓷从乳白色 变为深灰色。随后经过 $200{ }^{\circ} \mathrm{C}$ 加热 $10 \mathrm{~min}$, 着色陶瓷又变回到初始颜色, 显示出良好的光致变色行为。紫外照射 和反复加热循环可以有效调控该陶瓷的发光强度。且经过多次循环之后, 发光强度没有明显衰减。在紫外光照射下, $\mathrm{KNN}: 0.06 \mathrm{Eu}$ 陶瓷发光强度的可调比 $\left(\Delta R_{\mathrm{t}}\right)$ 高达 $83.9 \%$, 说明发光具有良好的可调性。进而结合发光中心和色心之间 的能量转移, 对 KNN:Eu 陶瓷的光致变色和发光机理进行了解释。

关 键 词: $\mathrm{K}_{0.5} \mathrm{Na}_{0.5} \mathrm{NbO}_{3}(\mathrm{KNN})$; 发光; 光致变色

中图分类号: TQ174 文献标识码: A 